\title{
Dispute Resolution Procedure for public information at the Aceh Information Commission (KIA) Through Mediation and Adjudication
}

\author{
Tasmiati Emsa', Syafei Ibrahim², Tommy Hariyanto $^{2}$ \\ ${ }^{1}$ Social Sciences Doctoral Study Program, University of Merdeka Malang, Indonesia \\ ${ }^{2}$ University of Merdeka Malang, Indonesia \\ Corresponding Author: Tommy Hariyanto
}

Indonesia

\begin{abstract}
The Aceh Information Commission has the authority to settle Public Information Disputes through mediation and/or nonlitigation adjudication, so in the context of carrying out the dispute resolution function, the Aceh Information Commission has a procedure that regulates the procedure for how a case is submitted, until the procedure for the Board of Commissioners gives a decision. In the Public Information Disclosure Act (KIP), it has been regulated as in Chapter IX starting from Article 40 to Article 46, and furthermore it has also been regulated in Information Commission Regulation Number 1 of 2013, concerning Procedures for Settling Public Information Disputes or abbreviated as PPSIP. This study aims to describe and analyze Public Information Dispute Resolution Procedures at the Aceh Information Commission through Mediation and Adjudication, as well as describe and analyze Encouraging Factors and Obstacles to Procedures for Settling Public Information Disputes through Mediation and Adjudication. In this research, the writer uses a qualitative approach, with the consideration that the writer intends to obtain an in-depth picture of a particular social phenomenon in the sense of describing the Procedure for Resolving Public Information Disputes at the Aceh Information Commission. To obtain data sources in this study through the selection of informants carried out deliberately (purposive sampling). Based on the type and source of data needed, data collection techniques used include (a) Indepth interviews, (b) Documentation Analysis, and (c) Direct Observation. In the process of data analysis techniques using an interactive model that includes three components of analysis, namely data reduction, data presentation, drawing conclusions. The results of this study indicate that the handling of dispute hearings does not necessarily take place after 14 (fourteen) working days after the dispute is registered. In 2018 there were 14 (fourteen) case registers whose stages of the Adjudication Hearing were completed in 100 (one hundred) working days. This shows that in the implementation there are still things that are not in accordance with the PPSIP regulations. Lack of socialization related to procedures for resolving information disputes to the public has not been evenly and continuously in the Regencies/Cities in Aceh. At present the court facilities and infrastructure are inadequate. The need to increase the capacity of the KIA Commissioner, increase the understanding of the Public Agency apparatus, and the public regarding procedures for resolving public information disputes, and it is hoped that the Government of Aceh will have a standard and balanced budget platform for the Aceh Information Commission.
\end{abstract}

Keywords: Adjudication, Public Information Dispute Procedure, Information Commission.

\section{INTRODUCTION}

Law Number 14 of 2008 concerning Public Information Openness (KIP) is a regulation that provides legal certainty for the public in obtaining information from public bodies [1]. The KIP Law also requires that information management and services be carried out by public bodies so that the public can get the widest possible access to information owned and managed by public bodies. Under the KIP Law it is stated that the function and position of the Information Commission is a state institution as an independent and independent supporting or supporting organ which is explicitly stated in Article 23 of the KIP Law. Article 23 of the KIP Law also explains the functions of other Information Commissions such as establishing technical guidelines for public information service standards and resolving public information disputes through mediation and/or non-litigation adjudication.

In carrying out the dispute resolution function, the Information Commission is required to have a formal law governing the procedure for how a case is filed, until the Board of Commissioners gives a decision. In the FOI Law, the information dispute procedure law has been regulated as in Chapter IX from Article 40 to Article 46, and subsequently has also been regulated in 
Information Commission Regulation Number 1 of 2013, concerning Procedures for Settling Public Information Disputes, hereinafter abbreviated (PPSIP). In addition to the two formal laws, there is also Supreme Court Regulation Number 2 of 2011 concerning Procedures for Settling Public Information Disputes in the Court.

Public information disputes are disputes that occur between public bodies and users of public information relating to the right to obtain and use information based on legislation. Public information requested by the Public Information Applicant is information that is generated, stored, managed, sent, and/or received by a Public Agency relating to the organizer and administration of the state and/or other organizers and operations of the Public Agency in accordance with the Law on Openness of Public Information and other information relating to the public interest. Information consists of information that must be provided and announced periodically, information that must be announced immediately, information that must be available at any time and information that is excluded.

According to statutory provisions, the PPID (Information Management and Documentation Officer) is obliged to serve requests for information in a public body. If PPID has not been appointed in the Public Agency, then there must also be a field whose function is to serve public information, such as public relations bureau or data and information center (Pusdatin), or others according to the terminology in each Public Agency. The point is that officials handle public information and have competence in managing information and documentation as regulated in Article 12 and Article 13 of Government Regulation Number 61 of 2010, PPID which must serve requests for public information [2]. The absence of PPID in a Public Agency does not eliminate the obligation of the Public Agency to serve requests for information from the public as well as possible.

If the PPID does not serve the application in accordance with the provisions of the law, including a period that has passed the 10 (ten) working day limit or with an additional 7 (seven) working days, then the Applicant has the right to file an objection to the PPID Boss, by sending an objection letter. PPID superiors or leaders of Public Agencies are given time to respond to the objection letter within 30 (thirty) working days, since the objection letter was received. If you have received a response from the PPID supervisor, but the Applicant is still dissatisfied or feels that the answer is not in accordance with what he has requested, or the request has been rejected by the PPID supervisor or the response is more than 30 (thirty) working days, then the applicant can sue the Commission Information to then be done dispute resolution.

It is at this stage that information disputes that occur between public bodies and users/applicants of public information are resolved through a process of mediation and/or non-litigation adjudication. In responding to the submission of a dispute resolution to the public information, the Aceh Information Commission must have begun to work on the dispute resolution process submitted by the Applicant within 14 (fourteen) working days after receiving the dispute request. Overall, the Aceh Information Commission is given 100 (one hundred) working days to settle a case, which is mentioned in Article 38 paragraph (2) the dispute resolution process can be settled at the latest within 100 (one hundred) working days from the date of receiving the information dispute resolution request. the public to the Aceh Information Commission until the verdict is read.

The process of resolving public information disputes at the Aceh Information Commission has two kinds of settlement, namely through a mediation process and/or non-litigation adjudication. Mediation is the settlement of a Public Information dispute between the parties through the assistance of the Aceh Information Commission mediator. Adjudication is the process of resolving public information disputes between parties at a hearing decided by the Aceh Information Commission.

Commissioner of the Aceh Information Commission tasked with receiving, examining and deciding information disputes. The authority of the Information Commission to summon and/or bring together the parties to the dispute, request relevant records or materials that are owned by the relevant Public Agency to make decisions in an effort to resolve the Public Information dispute, request information or present officials of the Public Agency or related parties as a witness in resolving Public Information disputes, taking an oath of every witness whose testimony is heard in the non-litigation adjudication of the settlement of public information disputes, conducts a local inspection to the Public Agency.

If the decision of the Non-Litigation Adjudication made by the Aceh Information Commission cannot be accepted by one of the parties, the relevant party can submit a dispute through the Court, namely the State Administrative Court and the General Court. If the decision of the Administrative Court or General Court cannot be accepted by the disputing party, then they can take legal action directly to the Supreme Court.

In 2018, based on the classification of requests for public information requested from the Public Agency, a total of 146 (one hundred and forty-six) requests for information. Of the classifications most requested are the Performance Report documents, there are 37 (thirty-seven) requests for information/data, following the classification of requests can be seen in the table below: 
International Journal of Advances in Scientific Research and Engineering (ijasre), Vol 6 (6), June -2020

Table 1. Request for Information Disputes Based on Information requested

\begin{tabular}{|l|c|c|c|}
\hline \multicolumn{4}{|c|}{ Dispute Request Data Based on Information Requested } \\
\hline \multicolumn{1}{|c|}{ Classification } & Amount & Classification & Amount \\
\hline List of Public Information & 0 & Financial statements & 20 \\
\hline Procurement of goods and services & 11 & Public Agency Profile & 5 \\
\hline Asset Management & 24 & Licensing & 5 \\
\hline Fund Source Info & 0 & Agrarianism & 4 \\
\hline Mine & 0 & The budget & 10 \\
\hline Public Agency Legal Products & 9 & Performance report & 37 \\
\hline LHKPN & 2 & SLIP & 0 \\
\hline Agreement contract & 1 & CSR & 0 \\
\hline RKA/DIPA/DPA & 13 & AD/ART & 0 \\
\hline The land & 0 & Infrastructure & 0 \\
\hline Law enforcement & 5 & TOTAL & $\mathbf{1 4 6}$ \\
\hline
\end{tabular}

Source: Aceh Information Commission Secretariat, 2018

In fact, a number of components of society still face obstacles in obtaining public information at the Public Agency. Never mind about the information that is excluded/confidential, public information that has been determined to be provided is still not obtained easily and quickly. This is known from a number of public information dispute submissions received by the Aceh Information Commission (KIA). The Aceh Information Commission still handles a number of public information disputes relating to basic matters in the provision of public information. This condition illustrates that the Public Agency has not worked seriously in providing public information to the public. This situation has an impact on the level of public participation and trust in state administrators. Access to public information is very important to ensure the level of public participation in development and the administration of the state that can be accounted for

The aim of this study to describe and analyze Procedure Settlement of Public Information Disputes at the Aceh Information Commission Mediation and Adjudication as well as describing and analyzing the Encouraging and Observer Factors of Procedures for Settling Public Information Disputes through Mediation and Adjudication.

\section{RESEARCH METHODS}

\subsection{Research Approach}

This research uses a qualitative approach, which is the approach used by researchers by basing on data expressed informants verbally or in writing, and also real behavior, researched and studied as a whole based on facts in the field to find out about the picture The role of the Information Commission in resolving public information disputes. The reason for the qualitative approach can be explained that an approach made persuasively to informants needed by researchers in order to obtain information in a dissertation completion.

\subsection{Method of Collecting Data}

Data collection methods using purposive sampling techniques, namely by determining the informants themselves who can be interviewed in accordance with the needs desired in research in order to explore the information that is the basis of theoretical design with the existence of research still carried out within the scope of the Aceh Information Commission. Thus the nature of the purpose of selecting samples in order to obtain information and choose people who allow researchers to study central issues so that they meet the requirements of good information that is conveying data as it is, honest, pleasant to talk and can communicate well, like other people, responsible and understanding the objects of research including mastering the information and being willing to share knowledge and uphold mutual trust. This interview was conducted with related parties only to support the study of documents. Based on the data sources required, the data collection methods in this study were carried out through: (1). Conduct interviews, (2) Direct observation, and (3). Documentation Study.

\subsection{Data Analysis Technique}

In analyzing the data the author uses a qualitative analysis method that is an analysis that describes the situation and events as a whole with a description conducted by researchers based on legislation, expert views, including the experience of researchers and the author's explanation in the field. The data analysis process is carried out simultaneously with data collection and then continued after the data collection is complete. The reduction process continued throughout the study. Presentation of data narratively after the data is obtained from the field through interviews and documents. Withdrawal of conclusions which in principle has been done from the beginning of data collection, where an analyzer starts looking for conclusions loosely and openly 
then increases to become more detailed and firmly rooted. Interactive Analysis of Matthew B. Miles and A. Michael Huberman in Jhoni and Saldana, The analysis process in this study was carried out in four stages, namely: (1). Data collection, (2) Condensation of data, (3) Presentation of data, and (4) Drawing conclusions [3].

\section{DISCUSSION}

\subsection{Mechanisms or Procedures in the Procedure for Implementing Public Information Dispute Resolution.}

Policy implementation is one of the most important stages in the policy process, implementation determines the success of a policy process itself to achieve the expected goals. Implementation is an activity that is related to the comple tion of a job by using means (tools) to obtain results. According to Pressman and Wildavsky (Wahab), implementation is a process of interaction between a set of goals and actions taken to achieve goals [4].

Furthermore in the book, Reality of Public Policy by Kridawati by Van Meter and Van Horn defines the implementation of public policy as: "Actions taken by public organizations that are directed to achieve the goals set in previous decisions . These actions include efforts to change decisions into operational actions within a certain period of time as well as in order to continue efforts to achieve major and small changes determined by policy decisions [5]."

To encourage implementation to run well, it is necessary to deliver information to the target to be addressed, the delivery of information can be done with socialization activities, both directly and indirectly. Dissemination is an importan $t$ stage in the implementation of a policy, but socialization activities are unfortunately still aware of the passive perspective of the community. The actual socialization is an effort to make the community aware and aware that there is a policy to be implemented that has a positive impact (generating benefits).

The Information Commission is the only institution authorized to settle Public Information disputes through mediation and/or adjudication, as stipulated in Article 23 of the FOI Law. There is no other institution or body that has the authority to do so. This is called the absolute authority possessed by the Information Commission in handling public information disputes.

Thus in carrying out the implementation of Information Commission Regulation Number 1 of 2013 concerning Procedures for Settling Public Information Disputes is one of the implementation of the order of Article 26 paragraph (1) letter c of Law Number 14 of 2008 concerning Openness of Public Information hereinafter referred to as the FOI Law, so that there are regulation for establish technical guidelines for public information service standards and resolve public information disputes through mediation and/or non-litigation adjudication, Information dispute resolution procedures are needed to provide legal certainty on the fulfillment of a person's right to information by the Public Agency as the party who controls information relating to the administration of the state and the public interest. As a judicial quasai institution, the procedure for resolving information disputes is established by applying the general principle of guarantee of access to information, namely fast, timely, low cost, and simple method [6].

\subsubsection{Calculation of terms and time period for filing a request to settle a dispute on Public Information.}

The requirements for submitting a request for a settlement of a public information dispute to the Information Commission are contained in the FOI Law and the Information Commission Regulation. For individuals, the basic requirement is enough to attach a photocopy of proof of identity, such as a National Identity Card (KTP), passport or other valid identity that can prove the Applicant is an Indonesian citizen.

For groups of people who authorize their dispute to a person or several people, it is enough to photocopy the identity of the authorized person and the identity of all those who give the power of attorney, accompanied by a power of attorney signed together on a stamp. Whereas for legal entities, a photocopy of the legal entity documents is required, including the condition that there must be a deed of establishment which is approved by the Ministry of Law and Human Rights (Kemenkumham). All proof of identity must be brought original at the beginning of the trial for an examination of the legal position (legal standing) plus the original KTP/PAspos for those authorized.

As for the complete administrative requirements other than as stated above, also must be attached/completed with the following documents:

a. Letter of request for information to PPID/Public Agency along with other supporting documents such as a letter of receipt at the destination Public Agency or proof of delivery from the Applicant;

b. Written notification or written response from PPID/Public Agency for information request letter, if any;

c. Objection letter from the Applicant to the PPID Supervisor/Head of the Public Agency along with other supporting documents such as a photocopy of the letter and receipt of the letter at the destination Public Agency or proof of delivery from the Applicant;

d. Written response letter from PPID/PPID supervisor/Head of Public Agency over objection from the Applicant, if any;

e. Other supporting documents according to the applicant are needed to strengthen the reasons for the application of the dispute if any.

After the request for submitting or registering a dispute to the Aceh Information Commission and considered to meet the requirements and staysa time by the registration officer/staff, then issues the registration deed of the public information dispute 
case. In the register deed, the case registration number and the disputing party will be listed. According to regulations, actually 14 working days after the issuance of the registration deed the trial process for the resolution of information disputes at the Aceh Information Commission must have begun. However, the handling of the dispute trial does not necessarily after 14 (fourteen) working days after the dispute is registered.

\subsubsection{Determination of the Method, Agenda and Schedule of the Session.}

In determining the method, agenda and schedule of the communication session, it plays an active role in the process of resolving public information disputes in the Aceh Information Commission (KIA), communication will be established between staff and commissioners, substitute registrars will also communicate with the parties both the Petitioners and Respondents, several matters what the parties to the dispute need to know are the stages before the trial. Some things that need to be known before the trial is about the registration deed, the Board of Commissioners, the Mediator, Registrar, substitute registrar and trial support staff.

After obtaining the deed of registration, the Petitioners and Respondent are just waiting for a summons from the Aceh Information Commission, based on Article 24 paragraph (2) of the Information Commission Regulation, stating that the summons must have been received by the parties or their attorney no later than 3 (three) days work before the first day of adjudication and mediation.

Based on the rules of the Information Commission Regulation, the process after obtaining the deed of registration, the Petitioner is just waiting for a summons (relaas) from the Registrar/Registrar substitute for the Aceh Information Commission. Likewise, the Respondent will be summoned together with the Petitioner. Will be sent by the KIA officer on the order of the Registrar/substitute registrar at the latest 3 (three) working days before the first day of the adjudication and mediation session. But in reality sometimes 2 (two) days and even 1 (one) day we receive the call for trial in the Aceh Information Commission received by both parties, so we do not have time for procedures for making power of attorney and collect other documents that must be brought at the hearing.

\subsubsection{Substance of the material for filing a dispute request to the Aceh Information Commission.}

Good governance is a prominent issue in the management of current government administration. The intensive demands made by the community on the government to implement good governance are in line with the increasing level of public knowledge, in addition to the influence of globalization. The old patterns of government administration are no longer in accordance with the changing social fabric. Therefore, this demand is a natural thing and the government should have responded by making changes aimed at the realization of good governance.

Transparency is built on the basis of a free flow of information. The entire process is carried out by the government, public bodies, institutions, and information needs to be accessible to interested parties and the information available must be adequate so that it can be easily understood and monitored. Seriously, thoroughly and provide a place for active participation from all walks of life in the process of managing public resources. The principle guarantees that everyone has access to information related to government administration, namely information about the policy stage, the process of making, implementing, and the results achieved.

The main objective of the Law on Public Information Openness is to realize a good, open, accountable, effective, efficient and accountable state administration as well as an active role of the community in public policy making, as well as involvement in building clean and good governance in Indonesia.

The obligation of the government to provide public information under its authority, both information available at any time, periodic information, information is necessarily in addition to information that is excluded by public bodies. In the event that the information applicant wishes to obtain information, it can submit requests for public information to the public body in writing.

The Government/public body has the obligation to provide answers to requests for information received within a period of no later than 10 (ten) working days from the receipt of the application and can extend the time no later than 7 (seven) working days by sending written notice to the applicant. If the response of the public body is deemed not in accordance with the request for information, then the Applicant can submit an objection to the PPID supervisor. Within 30 (thirty) working days objections to superiors were not responded to, the applicant for information submitted a request for dispute resolution to the Aceh Information Commission (KIA). Material substance becomes an administrative requirement for filing requests for information dispute resolution.

It can be concluded that the material substance is the submission of a dispute request to the Commission Information on Aceh must be examined at the stage of submission, to see the substance of the petition, whether the case being disputed is an information dispute, or a criminal or civil case. As well as whatdisputed information is open public information or exempt public information.

\subsection{Mediation and Adjudication Procedure}

In the terminology of public information disclosure, public information disputes are defined as disputes that occur between public bodies and users of public information relating to the right to obtain and use information under the Public Information 
Disclosure Act No. 14 of 2008. In public information disputes, disputing parties or the one suing is referred to as the Petitioner. These applicants can be individuals, groups of people, or legal entities, provided they are Indonesian citizens and Indonesian legal entities. While the disputed or sued party is referred to as the Respondent, namely the leadership of the Public Agency.

In general court, a person who hears or hears a case is called a judge or collectively is called a panel of judges. But the people who handle public information disputes at the information commission are not called the Panel of Judges, but rather the Board of Commissioners. The hearing at the Information Commission will be handled by judges called the Board of Commissioners. Once they get the Aceh Governor's decree and decree, they automatically become lawful judges on public information disputes, called the Board of Commissioners.

In a case register that is handled, in general the number of the Board of Commissioners is odd. One of the Commissioners must act as a mediator in one case, namely one Commissioner who is not a member of the Board of Commissioners in the a-quo case, meaning that for a case register it is actually handled by 4 (four) commissioners.

\subsubsection{Examination of Court Proceedings}

In the process of resolving public information disputes at the Aceh Information Commission (KIA), a number of things need to be known in stages before the trial. Before conducting the trial, it is necessary to know about the registration deed, the Board of Commissioners, the Mediator, the Registrar, the Substitute Registrar, and the court support staff. When the Petitioner submits a request for dispute resolution to the Aceh Information Commission (KIA), then the staff of the secretariat officer who receives the dispute request also the Substitute Registrar will check the completeness of the administrative submission of the request, the officer issues a receipt for the dispute resolution request that has been checked in completeness, such as: fphotocopy of Personal Identity, Request for Information Dispute Resolution, Request for Information, Receipt, Request for Information, Response Letter for Information Request, Objection Letter, Objection Receipt, Objection Reply Letter, Photocopy of Republic of Indonesia Kemnkumham Notary Letter of Power of Attorney SK, Association of Institutional Information, and ADRT Foundation.

That in addition to the requirements for the examination of the completeness of this trial, it must be completed before the start of the trial, the staff, and also the substitute Registrar must also check the completeness of other hearings, namely the attributes of the trial. The professional attitude of the board of commissioners in examining the completeness of the trial is absolutely necessary for this factor. In a professional, timely/timetable, polite, ethical, based on applicable rules will make the growth of public trust as an institution that resolves disputes over public information. It can be concluded that the terms in completed before the trial, namely completeness of documents in the form of KTP/other identities, power of attorney if authorized, letter of request for information, and objection letter submitted to the public body and trial attributes.

\subsubsection{Stages of the Adjudication Session Process}

The number of trials at the Aceh Information Commission (KIA) can differ from one case to another. Several factors can affect several times a case can be resolved, for example a matter of whether or not 3 (three) matters were met at the initial/preliminary hearing (consisting of the authority of the Aceh Information Commission, the legal standing/legal standing of the parties, and the time period), the nature of the information which is disputed whether information is open or is excluded/kept confidential.

At the first preliminary hearing for a case register, then if both parties to the dispute or one of the parties are present, then the board of commissioners will begin to conduct a preliminary examination consisting of 3 (three) things, namely:

1) The authority of the Aceh Information Commission $(\mathrm{MCH})$ which hears the case, both absolute authority and relative authority;

2) Legal standing or legal standing of the parties or their proxies; and

3) Time scheme or calculating the time period from the request to submit information request to the Public Agency/PPID, filing an objection to the PPID Superiors, to registering the dispute with the Aceh Information Commission (KIA).

Also the willingness of the parties both the Petitioner and Respondent to take the mediation path if information is open, the level of complexity (volume) and volume of information disputed, and the available evidence if the case is not resolved in mediation but must be adjudicated by non-litigation. Also depends on the seriousness of the parties to speed up the trial, such as the level of attendance at the hearing, about the completeness of the documents they must bring, the convoluted or not giving information, and others.

In the stages of the Mediation and Adjudication session, the board of commissioners has the authority to summon and bring together the parties, so physically the Petitioners and Respondent parties are required to be present at every stage in the hearing, the commissioner panel asks for relevant notes or materials that are owned by the Public Agency to make decisions, request information or present an official of a public body, take an oath of witnesses/experts, this will be the legal facts of the trial. 
International Journal of Advances in Scientific Research and Engineering (ijasre), Vol 6 (6), June -2020

Table 2. Session Stages at the Aceh Information Commission

\begin{tabular}{|l|l|l|}
\hline No. & \multicolumn{1}{|c|}{ Stages } & \multicolumn{1}{c|}{ Regulation } \\
\hline 1 & Preliminary Examination Session & Article 35 to Article 37 \\
\hline 2 & Mediation Stages & Article 38 to Article 50 \\
\hline 3 & Proof of Hearing & Article 51 to Article 55 \\
\hline 4 & Local Inspection & Article 56 \\
\hline 5 & Conclusions of the Parties & Article 57 \\
\hline 6 & Amar Decision & Article 58 to Article 61 \\
\hline
\end{tabular}

Based on the rules in the Perki PPSIP and UU KIP, the dispute resolution process must endeavor to be settled no later than 100 (one hundred) working days after receiving the request from the Applicant, and be registered at the Information Commission until the reading of this decision is also regulated in the provisions of the Regulations in the Information Commission. There is a case register where the stages of the Adjudication Trial are completed in 100 (one hundred) working days. In the Information Commission Rule in Article 59 paragraph (4) says a copy of the Decision is given to the parties within a period of no later than 3 (three) days after the decision is read out in a public hearing, but in its implementation only 5-10\% of the decision's ruling is given to the parties within a period of 3 (three) days.

\subsubsection{Good Faith of the Respondent and the Petitioner}

Good faith is an abstract understanding and difficult to formulate. The large Indonesian dictionary (1999) defines good faith as something appropriate without guile or trickery. Although the principle of good faith is understood as one of the important and influential principles in contract law, there is no comprehensive definition that can explain the meaning of good faith itself According to Indonesian Supreme Court Regulation (PERMA) number 1 of 2016 concerning Mediation Procedures in the Court of Good Faith in the mediation process and the legal consequences of parties who have no good faith in the mediation process. Article 7 states as follows:

1) The Parties and/or their attorneys must take mediation in good faith;

2) One of the parties or Parties and/or their attorneys can be declared in good faith by the Mediator in the case concerned:

a. not present after being properly summoned 2 (two) times in a row at the Mediation meeting without valid reason;

b. attend the first Mediation meeting, but never attend the next meeting even though it has been appropriately summoned 2 (two) times in a row without a valid reason;

c. repeated absence that interferes with the Mediation meeting schedule without valid reason;

d. attend a Mediation meeting, but do not submit and/or not respond to another party's Case Resume; and/or

e. did not sign the concept of the Peace Agreement which was agreed upon without valid reason.

From the author's observations, there are several dispute registers at the Aceh Information Commission whose mediation agreement did not provide the information/documents requested by the Petitioner, whereas in the mediation agreement the Respondent promised to submit as the mediation agreement results. Weak follow-up of the Public Agency in implementing mediation agreements as outlined in the Mediation Decision to provide information/documents agreed upon in the mediation process.

In the trial stages at the Aceh Information Commission the Respondent and/or their attorneys were not present at the hearing, even though, PPSIP, the Board of Commissioners was able to examine and decide upon disputes without the presence of the Respondent. Even though the substitute registrar properly sent the court summons to the Respondent and the Petitioner. In reality it showed that the Respondent most frequently did not attend the trial process. This will result in delays in the trial process, so we must reschedule the trial.

Furthermore, for the Petitioner there are many dispute registers requesting requests in large quantities. Requests that are not made in earnest and good faith as referred to in Article 4 paragraph (3) of the Information Commission Regulation on PPSIP, have been explained to make requests in large numbers at once or repeatedly but do not have clear objectives or have no relevance with the purpose of the application.

The good faith of the Respondent and the Petitioner in the trial process can be concluded as follows: it is very important to pay attention so that the trial process can go well, if this good faith is not heeded it can automatically disrupt the trial process, and if the information is not given by the Public Agency the Petitioner's right to obtain information is very harmed. 


\subsection{What factors are driving the implementation of policies on procedures for resolving disputes over public information through mediation and adjudication.}

\subsubsection{Internal Driving Factors.}

a. Facilities and infrastructure of the courtroom.

In general, facilities and infrastructure are tools that support the success of an effort made in public services. Because if these two things are not available, all activities can not achieve the expected results according to plan. Means are all types of equipment, work equipment and facilities that function as the main tools/assistants in carrying out the work, and also in the context of interests that are related to the work organization. clearly gives direction that the facilities and infrastructure are a set of tools used in a process of activities both those tools are auxiliary equipment and main equipment, both of which function to realize what is to be achieved and improve performance.

Since the establishment of the Aceh Information Commission (KIA) in 2012 until 2019 for the trial activities of the Aceh Information Commission using the Information and Communication Office Office of Aceh which is located on STA Mahmudsyah Street No. 14, Baiturrahman District, Banda Aceh Postal Code 23243. Until now the Information Commission office Aceh does not yet have a room to be used as a courtroom.

To conduct a trial the trial attributes must be, such as the board nameplate, the nameplate of the substitute Registrar, hammer, recording device, camera, video, tripod, flag, national emblem, Scripture, Board of commissioner's assembly book, Substitute Registrar's agenda, laptop, calendar, wall clocks, trial recording equipment, commissioner coats, substitute court clerks, attendance attendants, applicants, printers. While the distance between the Office of the Aceh Information Commission (KIA) with the Office of the Ministry of Communication and Information and the Aceh Archives $\pm 2.6 \mathrm{~km}$. So that staff or officers appointed to handle court property/equipment must prepare the courtroom every day, and guarantee the proper functioning of the sound system equipment in the courtroom. Sometimes because the Aceh Information Commission borrowed using the Information and Communication Hall room, when the Aceh Communication and Information Commission held an event, the trial had to be postponed, even though they had received calls from both parties.

The Aceh Information Commission is required to have a permanent courtroom without having to borrow or use it in the Aceh Information and Communication Office Hall, the courtroom is a space used to hold examinations, hear and decide a public information dispute in the Aceh Information Commission (KIA) court.

b. The existence of the role of the Board of Commissioners in the settlement of public information disputes.

The Aceh Information Commission is legally authorized to settle requests for resolution of public information disputes. Authority consists of absolute authority and relative authority. Absolute authority is the authority to resolve public information disputes. Relative authority is the authority to settle public information disputes concerning provincial level public bodies and/or district/city level public bodies.

The tasks of the Information Commission related to the resolution of public information disputes in accordance with Article 26 paragraph (1) of Law Number 14 of 2008 concerning Openness of Public Information:

(1) Information Commission on duty:

a. Receive, examine, and decide upon requests for resolution of public information disputes through mediation and/or nonlitigation adjudication submitted by each request for public information based on the reasons referred to in the law on public information disclosure. "

Based on this task, Article 27 paragraph (1) of Law Number 14 of 2008 concerning Public Information Openness states that the Information Commission has the following authorities:

1) Summon and/or bring together the parties to the dispute;

2) Request relevant notes or material that is owned by the relevant public body to make decisions in an effort to resolve public information disputes;

3) Request information or present officials of public bodies or related parties as witnesses in the settlement of public information disputes;

4) Taking the oath of every witness whose testimony is heard in the non-litigation adjudication of public information dispute resolution.

The public information dispute hearing at the information commission is a "light" and simple trial, the risk is not severe. Therefore, the resolution of public information disputes must be done quickly, simply and at a low cost. And even for simple open information dispute resolution. 


\subsubsection{External Driving Factors.}

a. Rules and Regulations.

From the observations made by the author, the implementation of dispute resolution has a strong legal basis as a rule of its implementation, as well as in carrying out its duties, and the role of the Information Commission of course also has a legal basis as its reference. Regulations become very important besides facilities and infrastructure as well as Human Resources, therefore the Aceh Information Commission before exercising authority in resolving public disputes has certainly done a study of how roles and tasks can be carried out, what is the legal basis, there are no rules that require to be carried out. Therefore the policy implementation approach formulated by Van Meter and Van Horn is called A Model of the Policy Implementation [8]. This implementation process is an abstraction or performance of a policy which is basically intentionally carried out to achieve high performance of policy implementation that takes place in the relationship of various variables. This model presupposes that policy implementation runs linearly from political decisions, implementers and public policy performance. This model explains that policy performance is influenced by several interrelated variables, in detail the variables of the implementation of the Van Meter and Van Horn public policy models are explained as follows: implementing and public policy performance. This model explains that policy performance is influenced by several interrelated variables, in detail the variables of the implementation of the Van Meter and Van Horn public policy models are explained as follows: implementing and public policy performance. This model explains that policy performance is influenced by several interrelated variables, in detail the variables of the implementation of the Van Meter and Van Horn public policy models are explained as follows:

1) Policy standards and objectives/policy measures and objectives.

2) Resource.

3) Characteristics of implementing organizations.

4) The attitude of the implementers.

5) Communication between related organizations and implementation activities.

6) Social, economic and political environment.

The policies implemented must have a strong legal basis. Because the policy is something that must be analyzed in depth on various alternatives that lead to a decision. When referring to the KIP Law and Information Commission Regulation number 1 of 2013 concerning Procedures for Settling Public Information Disputes, the procedural law for dispute resolution is, a series of regulations that contain provisions of procedures, procedures for regulating how individuals, institutions, must act and authorized to settle public information disputes.

The Information Commission is the only state institution that is given absolute authority to resolve public information disputes through mediation and/or adjudication. In this regulation also regulates Criminal sanctions, because without sanctions there is no compliance and public information disclosure will not grow in the bureaucracy.

b. Community's understanding of information dispute resolution.

Since the enactment of Law Number 14 of 2008 concerning Openness of Public Information and Regulation of the Information Commission Number 1 of 2013 concerning Procedures for Settling Public Information Disputes, not all people have received and received education related to the regulation.

Procedures for resolving information disputes are needed to provide legal certainty in fulfilling a person's right to public information by a Public Agency as the party who controls information relating to the administration of the state and the public interest. The public, both private and representative of the organization, have begun to understand that there is a right of the people to access public information relating to public bodies. The public already knows that there is a law guaranteeing that everyone has the right to seek, obtain, own, store, process information using all types of available channels.

All this time socialization related to information dispute resolution procedures in districts/cities has never been carried out. The Government of Aceh and the Aceh Information Commission have a role to carry out dissemination to the villages. And the Public Agency in carrying out its functions, facilitates work in providing information to the public to the public, thereby providing greater opportunities for the people to participate in various public policies. especially with the establishment of Information Service centers in each Aceh Government Work Unit (SKPA), of course it will facilitate the public in accessing various public information in determining policies, so that future governance of the Government of Aceh will be better and transparent.

The media is one of the tools in the context of educating the public, especially in understanding the information disclosure material in public bodies, so that people are more aware of their rights and procedures for requesting information and the consequences of sanctions if the information is misused. Community understanding of community information dispute resolution is still lacking. It is hoped that the Aceh Information Commission and the Government of Aceh can strengthen the community to conduct socialization so that the community is also aware of their rights and obligations, both the Public Agency at the Regency/City level as well as the community, so that they can contribute fully in supervising development policies. 


\subsection{Obstacles to the implementation of policies on procedures for resolving disputes over public information through mediation and adjudication.}

\subsubsection{Internal Inhibiting Factors.}

a. Personal capacity of the Commissioner of the Aceh Information Commission (KIA).

The success or failure of the implementation of the FOI Law cannot be separated from the role of the institution that is mandated to carry it out, namely the Information Commission. therefore this institution must be managed properly and professionally by people who are indeed professional, capable, and have integrity. But in reality, this is still not as expected and still far from the objectives mandated by the law.

There are 4 (four) things that must be considered so that the information commission becomes independent, more empowered, bertaji, respected, trusted, and able to realize the objectives of the law as stated in Article 3 of the FOI Law. These four things are complementary and cannot be ignored one of them, and requires serious effort. Two things are something given, while the other two things have to go through struggle and hard work.

Broadly speaking, the education function prepares the generation to have the ability to be able to play roles in social life. transferring knowledge related to roles in the public. Transferring values with the aim that the integrity and unity of the community is maintained, as the main condition for the life of a society and also civilization.

According to Gibson said: The ability to show the potential of people to carry out tasks or jobs. That ability may or may not be used. The ability is closely related to the physical and mental abilities that people have to carry out work and not what they want to do. Here the conceptual ability of a person as a decision maker in analyzing and formulating the tasks they carry. With this conceptual ability, the work can be directed and run well because it can choose which work priorities should take precedence and before work tends to use priority scale [7].

Education indirectly can affect the mindset and behavior in understanding the ins and outs of the duties and functions of the Information Commission. Educational requirements and discipline levels are not regulated in the recruitment to become a Commissioner for the Aceh Information Commission. This greatly impacts the performance of the Information Commission in resolving public information disputes.

The need for capacity building for the Board of Commissioners as a judicial quasai body in carrying out information dispute resolution procedures to provide legal certainty in fulfilling a person's rights or information by a Legal Entity as the party that controls public information, as well as the Staff Capacity at the Information Commission secretariat.

In the KIP Law and the Information Commission Regulation which regulates the selection and designation of members of the Public Information Commission, the general requirements for becoming candidates for membership in the Public Information Commission do not mention the level of education. In the provisions for the prospective member of the Public Information Commission, only the government and community elements are involved. Therefore causing various interpretations in the conduct of the trial, the Commissioner of the Aceh Information Commission does not all understand or master the procedural law in the trial, because in the recruitment of members of the Public Information Commission there is no requirement of a legal degree education. So that it is necessary to increase the capacity of commissioners of the Aceh Information Commission in carrying out their duties to make decisions in the resolution of information disputes.

In addition, the lack of budget support for capacity building for Commissioners, whether through training, workshops, and seminars conducted by various agencies and other Information Commissions. The available budget has not responded to the ongoing dynamics, so the Commissioner of the Aceh Information Commission ( $\mathrm{MCH}$ ) is very difficult to meet the process of resolving public information disputes based on the principle of fast, precise, low cost and simple costs.

From the description above it can be concluded that the personal capacity of the commissioner of the Aceh Information Commission (KIA), it is absolutely necessary to increase the capacity of the Board of Commissioners to have the authority as a quasai judiciary in carrying out dispute resolution procedures to provide legal certainty in fulfilling a person's rights or information by the Public Agency as a public authority. control public information.

\section{b. The Ability of Registrar and Staff of the KIA Secretariat.}

To carry out and improve performance in carrying out daily activities, special abilities are needed as Registrar/Substitute Registrar/Secretariat Staff. KIA has the task of Settling Information Disputes so that the Registrar, Substitute Registrar or Staff, must also have special abilities as well so that the task of Settling Information Disputes can be carried out properly.

Whereas a substitute Registrar is an employee within the Information Commission appointed by the Registrar to be responsible for assisting/carrying out the duties of the Registrar. In the Information Commission, the duties of substitute registrars are numerous, because the duties of the Secretary of the Information Commission are occupied daily by the management, secretariat and financial support of the Information Commission, making it difficult for the clerks to carry out their full duties. If it is said that in the day-to-day operational duties of the Registrar in the Information Commission, mainly to handle the hearings, the need to increase the capacity of the substitute Registrar in preparing all the necessary equipment before the session, during the session and after the session of information dispute resolution. 
Article 1 point 6 of the PPSIP Regulation states that the registrar is the Secretary of the Information Commission responsible for managing the administration of dispute resolution requests, assisting the Mediator, assisting the Board of Commissioners in the hearing, recording the proceedings, preparing the minutes of the trial, and preparing a report on the results of the trial.

Whereas a substitute Registrar is an employee within the Aceh Information Commission appointed by the Registrar to be responsible for assisting/carrying out the duties of the Registrar. In the Aceh Information Commission, the roles of substitute registrars are numerous, because the duties of the Secretary of the Information Commission are busy with daily support from the management, secretariat, and financial support of the Information Commission, making it difficult for the clerks to carry out their full duties. However, the Secretary of the Information Commission as the registrar must make and sign the dispute registrar's own SK, cannot be represented by a substitute registrar. If it is said that in its daily operational duties the Registrar's operational duties in the Information Commission, mainly to handle the hearings, are more heavily relied on by substitute clerks.In 2018 there was 3 (three) contract staff become Substitute Registrars, and the three substitute Registrars also carry out other office administrative tasks. Although the number and capacity of the staff of the secretariat requires an increase and increase in personnel, up to 2018, this request has not yet been made. At present secretariat staff whose status is honorary, there are no special staff whose primary duties are merely substitute registrars.

The lack of budget support for capacity building for Registrar/Substitute Registrars and Secretariat Staff, whether through training, workshops, or seminars conducted by various institutions and the Central Information Commission. There are 3 (three) honorary staff in charge or serving as substitute registrars. A Substitute Registrar since 2013 has been a staff member at the KIA secretariat and 2 (two) more people since 2014 became a Substitute Registrar, but only in 2018 followed the Bimtek Settlement of information disputes for clerks organized by the Central Information Commission held in Jakarta. This bimtek process enhances the ability of the Substitute Registrar in the KIA secretariat in carrying out their duties to assist the process of handling public information dispute resolution.

c. Budget availability at the Aceh Information Commission (KIA).

Speaking of budget problems, any changes in the implementation would require a budget, including in the framework of the implementation of Law Number 14 of 2008 on Public Information Openness in carrying out the duties and responsibilities of the Aceh Information Commission in resolving public information disputes. The budget is an important factor that must be a concern of all parties. Because without a budget, all sectors will be hampered. Included in the framework of providing a budget for dispute resolution as well as fields such as socialization, education and advocacy in all leading sectors of government/public agencies and the community in general in districts/cities throughout Aceh province. .

As an independent institution, the Aceh Information Commission must be able to carry out its mandate as an objective of the FOI Law, for this reason, it is necessary to support all parties so that Information Commission commissioners can provide optimal and optimal public services. This achievement can be fulfilled if various readiness of human resources and supporting facilities are available to carry out the duties and functions of the Commissioner of the Aceh Information Commission. But the facts show a different picture. Apart from having to carry out public information dispute resolution and socialization education agendas as well as advocating the implementation of the FOI Law, the Commissioner still has the responsibility to establish communication with the Executive and Legislative especially in terms of budgeting and managing the secretariat.

In fact, the lack of clarity in the amount of budget support and the MCH secretariat as an independent state institution, has caused serious problems, not including the provision of an adequate budget for resolving information disputes in the district/city and for socializing about the Public Information Disclosure Act. In addition, the lack of budget support for capacity building for Commissioners, whether through training, workshops, and seminars conducted by various agencies and other Information Commissions. The available budget has not responded to the ongoing dynamics, so the Commissioner of the Aceh Information Commission is very difficult to meet the process of resolving public information disputes based on the principle of fast, precise, low cost and simple costs.

\subsubsection{External Inhibiting Factors}

a. Understanding of Public Agency Apparatus.

From the results of observations and observations and public input, the authors found several things, such as the problem of understanding Public Apparatus Apparatus and the lack of commitment of the leadership of the Public Agency in the implementation of the Information Commission Regulation related to information dispute resolution procedures, being one of the obstacles that has not been maximized and the lack of compliance in providing information to the public so that it starts at a hearing at the Aceh Information Commission.

In general, the level of understanding of public bodies in Aceh related to the FOI Law, the Information Commission Regulation instrument on public information service standards and the Information Commission Regulation on Procedures for Settling information disputes is still relatively varied even below the standard because it is only tentative, incidental and casuistic. Not all Public Agencies have PPID, or have PPID, but they have not optimally implemented the Auth to provide information services 
according to the provisions of the Law and do not yet provide a budget for PPID. There are still many public bodies that do not know and understand the disclosure of information and procedures for resolving public information disputes.

The lack of understanding of the Public Agency apparatus and the commitment of the Head of the Office/Public Agency to the Aceh Work Unit (SKPA) or SKPK, causes every year an increase in information disputes that are resolved at the Aceh Information Commission (KIA).It is necessary to increase the capacity of the Public Agency Apparatus related to the procedure for resolving disputes over public information, in order to have adequate Knowledge and Human Resources and be able to carry out the Obligations of the Public Information Disclosure Service and Settlement of Information disputes based on applicable laws and regulations.

The inhibiting factors of Public Agency Apparatus Understanding that occur in understanding information dispute resolution procedures include:

1) Lack of understanding from the Apparatus in each work unit in the Public Agency, related to information dispute resolution procedures.

2) Lack of human resources in the Public Body that understands related to information dispute resolution procedures.

3) Data and information management in public bodies is still poorly structured so that it can hamper the trial of information dispute resolution

4) So the time needed in the process of the trial stages in the Aceh Information Commission is too long.

b. Mutation Officials within the Public Agency.

MThe official's utation is normal and reasonable, and it is a refresher, but hopes that the mutation is carried out in accordance with the rules and reviews who can be mutated immediately, because there must be considered. Because it is not easy to get functional personnel who can continue to carry out information service tasks if they have to think about mutations and careers at the Structural level.

The good thing is that the Government Public Body is starting to consider reviving functional positions in Aceh government work units. because all this time functional positions, public relations institutions, computer institutions, archivists, librarians and others are almost gone. This is important for the sustainability of the management of public services within the Government of Aceh, especially information services that directly confront the community. So that in answering and providing information does not exceed the day, as stipulated in the existing rules, when passing a predetermined day there will be an information dispute submission.

According to the author's observations of other external obstacles that also greatly affect the maximum number within the Public Agency, the high frequency of change and mutation of officials within the Public Agency, both in the SKPA and in the district/city SKPK. This of course becomes an obstacle that needs further study. Because the effect of the change of officials which is necessarily and without control will result in the fields of public service in all sectors. The Head of Office/Head/Section who is replaced and transferred must learn from scratch, the existing policies will be difficult to implement, so that it will result in low government performance, especially in providing information to the public.

Substitution of officials in a very short time within the Provincial and District/City level Public Agency, will affect the performance of the Government Apparatus, and will affect the understanding of the Public Agency apparatus related to information dispute resolution procedures. Information services that have been built before, will experience a vacuum due to officials and service officers being moved.

\section{CONCLUSION}

1) The authority of the Aceh Information Commission as an institution to resolve information disputes through Mediation and Adjudication has been regulated based on Information Commission Regulation No. 1 of 2013 concerning Procedures for Settling Public Information Disputes through Mediation and Adjudication, which has been carried out properly, in accordance with the stages.

2) Mediation is a very effective and fair form of information dispute resolution. This is because mediation is a deliberation with conflict between parties in dispute so that if mediation produces results, the result is a win-win solution. While non-litigation adjudication is a form of resolving information disputes that is quite time consuming, labor and cost, so the Aceh Information Commission should maximize information dispute resolution through mediation processes even though it cannot be denied that the information dissemination process of information disclosure laws and Information Commission Regulations concerning PPSIP are more effective at the time of adjudication because of its open nature and implementation.

3) Supporting factors, the regulation of the Aceh Information Commission institution which is given absolute authority to resolve public information disputes through mediation and/or adjudication, budget support and management of the Information Commission secretariat from the Government of Aceh, and the establishment of a very good and harmonious coordination and communication relationship with the Office of Communication and Information and the Aceh Archipelago. 
4) Inhibiting factors faced by the Information Commission in handling information dispute cases include the lack of understanding of the Public Agency regarding the FOI Act and the Information Commission Regulation on Information Dispute Resolution Procedures (PPSIP), the need for Socialization related to Regulations, Enhancing HR for implementors, courtroom and the existence of a standard and balanced budget platform..

\section{SUGGESTION}

1) The institutional strengthening and HR of the Aceh Information Commission must be interpreted as a medium and long term investment process. Strengthening is done through expanding the scope of authority, funding, human resources and infrastructure. So that the Information Commission as a quasi-judicial institution can transform into an independent, strong and authoritative institution.

2) The needUpgrade Understanding and Commitment of the leaders/officials of the Public Agency to understand the principle of transparency in managing information and providing information to the public so that people can participate in any policies implemented by public bodies or state administrators.

3) The Government of Aceh can take the initiative to form an independent institution to carry out the main tasks and functions of the Aceh Information Commission (KIA). This formation can be carried out through the Aceh Governor Regulation (Pergub) or stipulated through the Aceh Qanun.

4) Sociologically, there needs to be an awareness of all elements in information disclosure to evaluate the Information Commission Regulation number 1 of 2013 concerning Information Dispute Resolution Procedures to move towards improved regulations. Evaluation of the application of existing regulations is needed by involving the views of academics and relevant experts, as well as the State Civil Apparatus and the public.

\section{REFERENCES}

1. Undang-Undang Nomor 14 Tahun 2008 tentang Keterbukaan Informasi Publik.

2. Peraturan Pemerintah Nomor 61 Tahun 2010 tentang Pelaksanaan Undang-Undang Nomor 14 Tahun 2008 tentang Keterbukaan Informasi Publik.

3. Miles,M.B, Huberman, A.M, dan Saldana, J. 2014. Qualitative Data Analysis, A Methods Sourcebook, Edition 3. USA: Sage Publications. Terjemahan Tjetjep Rohindi Rohidi, UI-Press.

4. Wahab, Solichin A. 1991. Analisis Kebijakan dari Formulasi ke Implementasi Kebijakan, Bumi Aksara Jakarta.

5. Kridawati, Sadhana. 2011. Realitas Kebijakan Publik. Malang: Universitas Negeri Malang.

6. Peraturan Komisi Informasi Nomor 1 Tahun 2013 tentang Prosedur Penyelesaian Sengketa Informasi Publik

7. Gibson. 2009. Organizational: Behavior, Structure, Processes. New York: The McGraw Hill Companies, Inc.

8. Van Meter, Donald S \& Van Horn, Carl E. 1975. The Policy Implementation Process: A Conceptual Framework Administration And Society. Sage, London Vol.6 No. 4: 445-485. 